\title{
Praxeological conditioning of the decision-making process in environmental protection ${ }^{*}$
}

\section{Prakseologiczne uwarunkowania procesu decyzyjnego w ochronie środowiska}

\section{Grzegorz Embros}

Institute of Ecology and Bioethics, Cardinal Stefan Wyszyński University in Warsaw, Poland

ORCID: https://orcid.org/0000-0003-0861-6291・g.embros@uksw.edu.pl

\begin{abstract}
In the paper, the author attempts to identify the components and a course of the decision-making process in the area of environmental protection. Simultaneously, he pays attention to its conditions and context. The issues related to environmental protection are presented in a systemic approach with an emphasis on their practical nature. It is due to the necessity of decision making and a specific scheme of conduct. The author constructs such a scheme referring to a control system (in the context of a decision-making problems-solving) proposed by Marian Mazur and presented in the Deming cycle. At the same time, he points to the guidelines and characters of the efficient operation, whereby the broadly understood decision-making process becomes more efficient and more effective. He also pays special attention to the optimization stage including the selection of a precise (the most efficient and the most effective) action meaning a decision. The choice mentioned entails necessity of including certain criteria. Thus, it is disclosed that a decision-making process depends on the defined set of values.
\end{abstract}

Keywords: praxeology, axiology, environmental protection, decision-making process, optimization

Streszczenie: W artykule podjęto próbę identyfikacji komponentów i określenia struktury procesu decyzyjnego w ochronie środowiska. Zwrócono uwagę na jego uwarunkowania i kontekst. Problemy związane z ochroną środowiska przedstawiono w perspektywie systemowej, akcentując ich praktyczny charakter. Praktyczne działania na rzecz ochrony środowiska wymagają podejmowania decyzji, które mogą być ujęte w ramy określonego schematu postępowania. Autor konstruuje takie schematy odnosząc się do systemu sterowania zaproponowanego przez Mariana Mazura oraz cyklu Deminga. Wskazuje na wytyczne i formy sprawnego działania, dzięki którym szeroko pojęty proces podejmowania decyzji staje się bardziej efektywny i skuteczny. Zwraca szczególną uwagę na etap optymalizacji, a w tym na wybór najbardziej efektywnego czy skutecznego działania. Wybór ten pociąga za sobą konieczność uwzględnienia pewnych obszarów odniesienia. Wśród nich, poza obszarem prakseologicznym, wskazany został obszar aksjologiczny.

Słowa kluczowe: prakseologia, aksjologia, ochrona środowiska, proces decyzyjny, optymalizacja

\section{Introduction}

In the difficult art of decision-making process, it is important to adequately identify, classify and explain problems. Another important aspect is the proper incorporation of the obtained solutions into the process of indicating objectives. It is necessary to indicate an exhaustive list of measures to achieve the proposed objectives and to identify the side effects of each of them. As a result, it is possible to make an appropriate decision and proceed to implementation activities.
This issue is complicated mainly due to the fact that the decision-making process must take into account a great number of

" This article was originally published in Polish as Embros, Grzegorz. 2016. "Prakseologiczne uwarunkowania procesu decyzyjnego w ochronie środowiska" Studia Ecologiae et Bioethicae 14(1): 101-127. The translation of the article into English was financed by the Ministry of Science and Higher Education of the Republic of Poland as part of the activities promoting science - Decision No. 676/P-DUN/2019 of 2 April 2019. Translation made by GROY Translations. 
variables of different kinds. Decisions are influenced by a variety of factors influencing the decision-maker at different levels and in different intensity. These include factors that facilitate, hinder or sometimes even prevent the transition from decisions to actual implementation. However, it appears that, at the appropriate level of generality and with regard to a specific problem area, it is possible to identify certain principles, methods or mechanisms that increase the chances that the decision-making process will be successful and will result in appropriate activities.

This paper attempts to indicate the components and a course of the decision-making process in the area of environmental protection. Due to the consequences of the decision-making process in key areas for human and nature well-being, it is important that it is properly structured and implemented. Environmental protection activities more and more often include environmental engineering or nature conservation. They are based on the economisation of activities usually in only one version, indicated by management theoreticians, which is to strive for a maximum useful result at the lowest cost. The issue of costs is limited only to the financial result of the project, excluding, for example, social costs (e.g. closing a mine to reduce carbon dioxide emissions) or environmental costs (e.g. implementation of the investment with inadequate environmental impact assessment or without such assessment required by law).

There is an impression that especially among the participants of this decision-making process, a lack of knowledge about the need to take into account the conditions of the decision-making process prevail. The above statement inclines to address this issue to reveal important conditions and components of the decision-making process in environmental protection. At the same time, it allows for a thesis that if the context in which the process takes place is not taken into account and the general principles of "efficient operation" are not applied (praxeology), and the process does not refer to a specific set of values (axiology), it will be an inefficient, inappropriate, and defective process. It is hardly possible for it to contribute to development understood as "a process of change positively assessed from the point of view of a specific criterion; the basic criterion for assessing positivity is the value system (axiological criterion)" (Borys 2013, 560). The existence of an inefficient decision-making process in environmental protection contributes to the impossibility of achieving positive effects: natural, social, economic. As a consequence, such a process does not help to overcome, and may even lead to a deepening of the environmental crisis.

In the implementation of the discussed subject, it is necessary to present the problem area and the understanding of what environmental protection means. It is worth noting systematic sozology as the science of environmental protection in the concept of Józef M. Dołęga. Then it is necessary to address issues concerning the components, stages and mechanisms of the decision-making process. A reference will be made to the solving decision-making problems of Marian Mazur and the Deming cycle. It also seems justified to outline the context in which the decision-making process takes place. In particular, it is interesting to reveal its praxeological conditions.

\section{Environmental protection}

Numerous misunderstandings, errors or ineffective environmental protection measures may result from different definitions of environmental protection and different understandings of the terms "environment" or "protection". (or "care"). This paper is only able to highlight this problem. Many authors successfully explain these issues in different contexts. Therefore, it is worth mentioning the legal context (Boć, Samborska-Boć, and Nowacki 2008, 45), where the definition of environmental protection provided in the Environmental Protection Law is of significant importance; the context related to environmental (Poskrobko 2007, 47-49; Polski Komitet Normalizacyjny 2005, 3) or nature management (Dobrzański 2009, 
19-40; Lonc, and Kantowicz 2005, 17-22). It should be emphasised that differences in decision-makers' understanding of 'environmental protection' may consequently result in equally diverse effects, decisions and activities.

Considering the views of the authors addressing this issue and practitioners dealing with environmental protection, it is not justified to identify environmental protection only with nature protection or environmental engineering. It also does not seem possible to limit the issue to a narrow definition included in the Environmental Protection Law, which ignores important issues that currently exist in the vast area of environmental protection: "taking of an action or the abandoning of activities to allow the preservation or restoration of a natural equilibrium; in particular, such protection shall consist of rational development of the environment and management of natural resources in accordance with the principle of sustainable development, prevention of pollution, restoration of natural elements to their proper status" (Act 2001, $\mathbb{3}$ 3, p. 13). Attention should be paid to the "taking or failing to take action" emphasised in this definition and to limiting environmental protection to nature conservation.

Taking action to protect the environment requires solving problems of a theoretical and practical nature. They are characterized by a high degree of diversity and complexity. The systemic approach facilitates the correct identification, arrangement and subsequent resolution of these problems (Mazur 1976, 46-50). It allows presenting the system in its surroundings, taking into account key mechanisms, relations, properties and functions.

Systemic approach refers to the system and its surroundings. The environment is referred to as "anything outside the system under consideration that can influence the system [the system's external input] or that is influenced by the system [the system's external output]" (Kempisty 1973, 291). The system interacts with and influences its surroundings, causing it to transform. In the following part of the paper, the en- vironment will be understood as the surroundings transformed by the system. This transformation is the result of active system operation. Regardless of which system we are dealing with, its active operation, a specific dynamic is closely related to the spending and consumption of energy. The system uses energy (its replenishment requires the use of resources) to maintain its properties and functions (Zięba 2013, 94-131). These include couplings, mutual interactions between the system and its surroundings; adaptation related to the process of transformation by the system of its surroundings, yet also to the adaptation of the system to the influence of the environment it is transforming on itself; homeostasis - a state achieved through appropriate adaptation activities - which enables the system to function in its environment in a stable way.

Therefore, the question seems to be relevant: what system functioning in a particular environment can transform it in a way that results in its (the environment's) threat (destruction, degradation)? Common experience shows that only man transforms their surroundings on a scale and degree that can cause disturbances or complete degradation of the environment. Consequently, from the point of view of environmental protection as a system, it is justified to postulate that man, as well as society, should be exposed as a supersystem of the "man" system, in relation to the surroundings they are transforming, i. e. the environment. At the same time, the systemic approach's emphasis on the feedback of the system to its surroundings (and then the environment) also allows seeing the impact of this environment on the system that functions in it. The environment destroyed by man also destructively affects him.

Through their activities, people can threaten the (global and total) environment in which they live. The scale and degrees of impact may result in an increasing number of threats from the devastated environment. It thus leads to an environmental crisis (Hull 1998, 23-31; Hull 1990, 93-99). It seems that it can be described as a border situation in which people are 
forced to make certain decisions and actions (Piece 1983, 1392-1405). At the same time, only a human being can understand this and take appropriate decisions and actions to reduce or completely eliminate these threats. It makes analyses of the decision-making process a central point of environmental protection. Only man can destroy, yet also protect, and care for the environment. In this respect, the environment must be seen in multiple ways as actively and creatively transformed by humans (Hull 2006, 107-108). It means an environment in which both nature and culture are taken into account (science, technology, art and religion) (Dołęga 2002, 7-8).

Analyses conducted in this view make it possible to reveal key elements of the problem area in question and, consequently, to identify and define the objective. Environmental protection defined in this way will aim to preserve the properties and functions of the systems concerned and to shape the correct relations (harmonious interaction) occurring between their components (man-environment). These aspirations are intended to enable a man to live, survive and develop in the environment in which they function.

Depending on the way environmental protection is perceived, its subject is seen differently. Depending on how the term "environment" is understood, the environment itself and then what it is subject to is perceived differently (Dobrzański 2009, 19-48; Lonc, and Kantowicz 2005, 17-22). It may be interesting and practical here to refer to environmental science - sozology, which can be treated as a theoretical background for environmental protection. In the approach proposed by Józef M. Dołęga, sozology represents the science of "systemic protection of the biosphere against the destructive influence of the anthroposphere. [...] The sozology research, in general, is the interaction between the biosphere and the anthroposphere. In traditional language, it is a material subject of this science. Whereas the formal subject of sozology research is the protection of the biosphere from the destructive influence of the anthroposphere"
(Dołęga 1998, 36-40). In such a view, a set of specific activities aimed at protecting the environment for the benefit of the human being or the protection of the human being in the environment in which they function comes first.

The conducted systemic analyses made it possible to determine the practical nature of environmental protection. It is related to the need to take certain decisions and actions. This requires an indication of the purpose for which these actions are taken. The theoretical background that sozology can constitute for environmental protection was also mentioned. It seems appropriate to develop theoretical issues based on this science and then to implement them into practical actions for environmental protection.

\section{Scheme of conduct}

If the purpose of environmental protection is to provide people with the possibility to live, survive and develop, then an appropriate course of conduct is needed to ensure that this purpose is achieved. Continuing the systemic perspective, it is worth noting the proposal of M. Mazur a control system in the context of solving decision-making problems. It is also worth mentioning the so-called Deming cycle, mainly due to its frequent references and the role it plays in environmental management. The decision-making process will not be identified exclusively with an individual act of decision-making, rather in a broad sense represented by the aforementioned M. Mazur control system, included in the Deming cycle.

The main purpose of diagnosing such a specific decision-making process in environmental protection is to identify and indicate its constitutive features, components, properties and to reveal its deficiencies (in particular factors reducing its effectiveness or efficiency), to identify the sources of their formation and to determine the impact of the detected irregularities on the consequences, in relation to three capitals: social, natural and economic.

The decision-making process is influenced by the context in which it takes 
place. It is possible to identify problems that may significantly hinder decision-making in the area we are interested in. Above all, it should be noted that in the structure of reality only matter (animated and inanimate), or possibly energy, is noticed. As a result, environmental protection issues are reduced to, for example, environmental engineering, while environmental protection itself becomes the exclusive domain of natural sciences. Such a perspective leads to perceiving man solely as a consumer of resources or an issuer of harmful substances, and thus not far from the role of the perpetrator, who must be under the jurisdiction of environmental law. This perspective "flattens" the image of man. Therefore, the ethical or axiological dimension may be neglected.

It is also necessary to address the problems resulting from the conceptual and methodological chaos present in environmental protection. It makes it difficult to identify adequate tools, models and methods for identifying and solving problems (threats). At the same time, the importance of systemic approaches and information as an essential component of reality is neglected or marginalised. Decision-makers not only reveal a lack of knowledge (to the extent indicated here), they sometimes even declare it to be unnecessary. The negative attitude towards taking responsibility for man and the environment becomes apparent. On the other hand, in the event of an emergency, various forms of agreeing on justifications are practised, or attempts to transfer the consequences to people or other components of the environment (Kosewski 2008, 13-66). Deficiencies in this area may cause difficulties in properly identifying the objectives (Kay 2010, 2122). During the design phase, optimization is omitted, and some form of planning is sometimes implemented. Only economic capital is taken into account, while natural and social capital is neglected. The importance of a properly structured decision-making process in formalised environmental management systems is not recognised.
The phenomena and problems mentioned above do not facilitate decision-making. It becomes more important to indicate an appropriate course of conduct to minimise the negative impact of these factors on the decision-making process. In this respect, M. Mazur's proposal to define the control system as being at the same time a postulator, optimizer and implementer, seems interesting. This is because the control process requires the determination of changes to be made to the controlled system (postulation), methods (optimization) to cause these changes (implementation). This is how he constructs a set of three components. All these elements are linked to each other and the environment through feedback. The first component is the optimizer - responsible for optimization processes. There is a coupling between optimizer and the surroundings to ensure observation of the latter and methods of its modification. It is also coupled with the postulator - the second component of the system, responsible for indicating the objectives to be achieved. This coupling provides an opportunity to determine the interdependence of the methods and the objectives. The postulator is connected by feedback with the implementer - a component of the system responsible for the implementation of the objectives indicated by the postulator. The result of this feedback is that the interdependence of measures with objectives can be identified. The implementer is coupled with the surroundings, which results in the possibility to determine the measures of environmental modification and power supply (Mazur 1976, 102-103).

The control system described above takes into account the essential task of optimization. The task is to identify all the methods of action that can lead to the objective specified in the postulation and to identify the side effects of each of them. The indication of the optimal decision is entangled in detailed decision-making problems. Complications related to forecasting (including predicting the side effects of decisions) or the role of information in the decision-making pro- 
cess are also revealed. The problems in this area were indicated by Klemens Szaniawski (1994b; 1994a). Environmental management practice successfully applies risk analyses. This determines an acceptable or unacceptable level. Such an analysis provides support and a benchmark for decisions on activities that may have a specific environmental impact. It might be interesting to try to include guidelines for efficient operation and to include axiological issues in the design phase including optimization and timing of future actions (Gasparski 2004, 51-56). It appears, at least on a high level of generality, that this might lead to an optimal decision. The optimal decision subsequently results in the adoption of measures leading to an objective with the most favourable side effects (the essential criterion for optimization). In this way, methods for achieving a specific objective are indicated. The last stage of the decision-making process is the implementation of the objective indicated at the postulation stage, based on a previously optimized decision.

M. Mazur notes that "in this scheme, it is noteworthy that optimization and implementation are coordinate processes in relation to postulation. This means that not only methods and measures are dependent on objectives, and objectives are dependent on methods and measures, but by postulation, also methods are dependent on measures, and measures on methods" (Mazur 1976, 113).

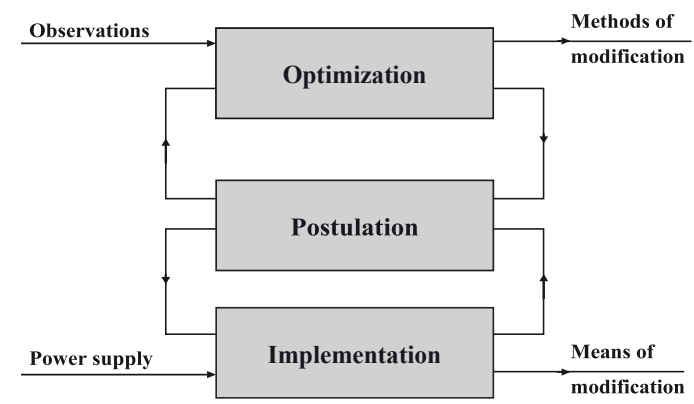

Fig. 1. Control system structure.

Source: (Mazur 1976, 114).
The value of the presented scheme is to highlight the optimization stage. It encourages the use of specific terminology and methodology in the entire decision-making process, while at the same time enables to include many important components that must be taken into account. As a consequence, it increases the probability of avoiding actions which have adverse side effects on many components of the controlled structure. This scheme helps to identify relatively few areas with a great variety of problems. Nevertheless, we obtain a highly complex set of many systems, connected by various dynamic relationships. This creates several difficulties. They result both from a comprehensive approach to such complex and complicated issues, as well as from detailed problems related to, for example, proper targeting, designing, planning or decision-making in the optimization process, determining (forecasting) side effects of decisions and actions taken, etc. It is essential to use tools supporting the described control process. The system approach can be mentioned here, due to which it is possible to include complex issues into an orderly structure of the layout of the components together with the identification and determination of relations between them. In the current of system solutions, one can refer to praxeology, the theory of decision or games. Since such an important role in the issue of control is attributed to the optimization and processing of information, it is worth to take into account the possibility of using knowledge supported by the most modern achievements of contemporary science and technology (information systems) (Michnowski 2003, 107-119; Michnowski 1999, 57-65).

In the context of the conducted analyses, a new and interesting perspective of reference to environmental protection issues is gained. As mentioned above, environmental protection measures are aimed at enabling people to live and develop. The "development" category in F. Piontek's view takes into account three types of capital: human, economic and natural, emphasizing human subjectivity and creativity (Piontek 2007, 
57-58). Considering man as a control system in M. Mazur's view, there may be three systems in the role of controlled systems: social, economic and natural. The equivalent of the term "control" may be the term "management", which is closer to everyday practice. Therefore, the mechanisms described may concern development management, taking into account all these factors (society, economy, nature) as equally valuable. In active management, a subject is a man, functioning and connected with the natural or economic environment. It is for human reasons that attempts are made to recover from the ecological or economic crisis. Irresponsible human activity leads to crisis situations in both areas. Inappropriate or incompetent management may be the cause of disturbances in the relationship between man and environment.

Environmental management is one of the key environmental issues. At this point, it is worth mentioning one more form of a scheme of conduct, namely the Deming cycle, especially since such a scheme is recommended in the ISO 14001 standard, based on which formalised environmental management systems are developed. As a result of their implementation, specific actions for environmental protection are undertaken, hence an adequate scheme of conduct is extremely relevant to the achievement of the objectives. Any deficiencies or defects of such a scheme may then translate into deficiencies or defects of the entire decision-making process and, as a result, into actions whose effects may be unfavourable to the environment and, consequently, to the individuals who function in it.

The international standard ISO 14001 is based on the methodology - Plan, Do, Check, Act (PDCA) (Polski Komitet Normalizacyjny 2005, 7-9). The standard does not clearly distinguish the optimization stage. The planning stage is followed by a transition to implementation activities. It is not evident that optimization procedures are automatically included in the planning stage. At this point, it should be emphasised that if in an area as complex as environmental protection which is translated into practical action, the plan has proved to be defective, then the practical effects of an improperly designed plan may also prove unfavourable. It appears that omitting the optimization stage in such an important and widely used model may have serious consequences for both the natural environment and man. In such cases, it is unjustified to reduce or eliminate the essential components of the scheme of conduct or to assume that they will naturally appear at the planning or implementation stage (Pszczołowski 1984, 318-325).

The decision-making process in environmental protection could be based on M. Mazur's control system, with particular emphasis on the optimization stage. It seems that it would be possible to add this component to the PDCA cycle, which emphasises checking and continuous improvement. Therefore, the environmental management system could be established on a more precise basis. Then, the chain of proceedings would include the following stages: solving cognitive problems (identification, classification, and explication) (Mazur 1976, 99-101); solving decision-making problems - in particular design or planning, which consists of optimization and definition of a schedule of actions as well as deployment and implementation. And then the subsequent stages of checking and reviewing the system and striving for continuous improvement, however, it should be possible to return to the optimization stage if any deficiencies are identified during the checking stage. The verification of the functioning of the environmental management system could take into account not only the quality of documentation or economic aspects but also praxeological and axiological or ethical evaluation. The latter can be done by referring to ethical management models (Gasparski 2013, 460-473).

\section{Praxeological guidelines}

Praxeology (gr. praksis - action; logos word, study of) - is the theory of efficient operation, a field of scientific research concerning methods of all purposeful human 
activity, especially its rationality, effectiveness, efficiency; one of its developers and leading representatives was T. Kotarbiński (Jedynak 1990, 558; Kotarbiński 1965, 358377, 394-408, 452-491).

At this stage, it is possible to indicate the principles of efficient action which should be included in the specific stages of the decision-making process described above. It would be justified to use them at the checking and optimization stage. At this point, it should be stressed that praxeology is about principles of action, not decision-making. It is more of a general nature than the theory of decision. As mentioned earlier, the key optimization in the Mazur's system is closely related to the choice of the best way to achieve the postulated objective, i.e. to an appropriate decision. This decision, in turn, involves identifying the side effects, that is, anticipating them. Both issues are connected (through the need to make a choice) not only with the need to have appropriate information, skills, competences (efficiency) or experience but also with the need to make certain valuations in the light of established criteria. This creates particular problems which are attempted to be solved, for example, by decision theory (Szaniawski 1994c). The objective of the efficient operation is to prevent chaos and disorder, measured by entropy. The basic forms (values) of efficient operation are effective (intentional), beneficial and cost-effective actions. An effective action means an action that leads to the desired effect (objective) (Kotarbiński $1965,113)$. When a performer does not go beyond the stage of intent, planning, postulating the objective, does not even come close to the intended objective - we are dealing with an ineffective action. Partially effective action is an action in which only some elements can be achieved, although they gradually become closer to the objective. In a situation where the action moves the performer away from the planned objective, the actions are counter-effective. However, when an action does not influence the achievement of a set objective, it is called neutral action. The effectiveness of action is limited to the facts intended as an objective - that is, the purposefulness of action. Therefore, inefficiency is purposelessness, and counter-effectiveness is counter-purpose, and neutral action is neither purposeful nor counter-purpose (Kieżun 1997, 19; Kotarbiński 1965, 113-116).

One of the forms that efficient operation take is profitableness. Kieżun describes it as the difference between the useful result (W) and the cost of the action $(\mathrm{K})$. He lists three cases. In the first, the useful result is greater than the cost of the action - it is a beneficial action. In the second, the useful result is equal to the cost of the action - it is a benefit-neutral action. Unfavourable actions are those where the useful result is lower than the cost of the action - this is the third case referred to by this author. Kieżun also presents options for the link between the effectiveness and the benefits. The first relates to effective but unfavourable actions. This is a situation where the achievement of the objective is followed by unintended side effects. This is an example of negligence or mismanagement of the optimization process. In environmental protection practice, an example may be various types of installations (also "pro-environmental", “clean", "green”, etc.), which during operation generate unexpected negative environmental or social effects at the postulation and planning stage (e.g. operation of wind turbines in close proximity to residential buildings). Kieżun refers to the example of a factory where, although it achieves the intended profit of USD 1 million per year (the objective: the construction of the factory has been achieved), unintended environmental pollution causes losses of USD 2 million a year. As a result, the action is unfavourable.

Another type of action is ineffective, but beneficial action. In this case, the objective has not been achieved, however, the unintended effects are assessed positively and exceed the value of the unachieved objective. Effective and beneficial action is an example of efficient operation, while ineffective and unfavourable action is completely inefficient.

It is also worth mentioning the ad-hoc ineffective measures whose benefits are 
deferred (Kieżun 1997, 19-20). This is important due to the need to include a time perspective in the assessment of benefits. Such delayed, desired positive environmental or social effects are common in environmental practice (Żylicz 2004, 28-42).

Another basic form of efficient operation is cost-effectiveness, which is measured by the ratio of useful/cost-effective result (W) to the cost of action (K). It should be emphasised "that this is a different concept from the one used in economics, as praxeology takes into account both material and moral costs" (Kieżun 1997, 20). As in the case of beneficial actions, there are three options - cost-effective, not cost-effective and economically neutral actions. Although cost-effectiveness is in the same class of concepts as a benefit, appropriate distinctions must be made between them. The main reason for this is that, in practice, the most beneficial option is not always the most cost-effective. Therefore, as regards the selection of the action options, the criteria of cost-effectiveness and benefits are separate (Kotarbiński 1965, 121-122).

Seeking to maximise the ratio of the useful result to the costs of the action is defined as the economisation of the action. In other words, it is about finding a more cost-effective way to act. Several possible options for action are also indicated in this case. The first is to maximise the useful result at fixed costs (productivity option). In the second, with a fixed useful result, costs are minimised (the cost-saving option). In the third option, the result is maximised (increased productivity), costs are minimised (increased savings) (Kieżun 1997, 20).

"Action is the more efficient the more forms of action it includes" (Kieżun 1997, 22). There are two groups of efficient operation forms - the first concerns the manner of action, the second relates to the effect of the action. The first group includes simplicity, energy and purity, and the second group includes successful adaptation, accuracy and reliability.

According to Kotarbiński, the action is simpler when it is less complicated (Kotarbiński 1965, 125-126). Therefore, a man- ner of action is simpler when it consists of a few simple actions, linked together in an uncomplicated way. Kotarbiński also points to the energy, by which he means an action in which a sufficient amount of energy is spent. In other words, the agent puts in the action everything that is needed. The author lists the following as detailed figures: briskness, resourcefulness, conscientiousness, diligence, persistence (Kieżun 1997, 22; Kotarbiński 1965, 139-142). Kotarbiński introduces the notion of purity of a product - the greater the purity of a product, the less negative features it has, which are incompatible with the main or secondary objective. He points out the presence of damage, undesirable features, contamination, etc. in the product. A product free from these defects allows for the evaluation of the action itself, associated with its formation as pure action. He defines it as a unique example of a cost-effective action (Kotarbiński $1965,120-121)$. It seems that contemporary terminology uses, in a similar context, the term "quality" instead of "purity" to describe actions or products.

In the second group, in which the form of efficient operation refers to the effect of the action, Kotarbiński places successful adaptation - a form of efficiency which is characterised by the inclusion of not only main but also secondary objectives in the action and product. He also refers to the accuracy, which consists in reproducing the pattern in a similar way to the pattern. He defines it as follows: "the more accurately a task is performed in a given respect, the less the production differs from the pattern in that respect" (Kotarbiński 1965, 117). Reliability occupies a significant place in this group. Reliability occupies a significant place in this group. It may be related to the functioning of tools in accordance with their intended use, the robustness of the product, as well as human submissiveness (a submissive person is a person you can depend on). Two important statements are connected with the concept of reliability. The first one states that "the reliability of the whole system (organisation) is a function of the reliability of its individual components. The reliability of 
a system consisting of elements connected in series is a product of the reliability of its individual elements. A slight decrease in the reliability of individual elements reduces the importance of the reliability of the whole system, and vice versa, a slight increase in the reliability of these elements significantly increases the reliability of the whole system" (Kieżun 1997, 23). The second statement is that "the reliability of a system consisting of a sufficient number of back-up elements, which are connected in parallel in an alternative way, is equal to the probability that not a single element will fail. If only one of the elements does not fail, the whole system will be reliable" (Kieżun 1997, 23).

These forms of efficient operation translate into cost-effective actions. They are graded and take the form of productivity or savings. The behaviour is the more productive, the more valuable output it provides with given defects; it is the more cost-effective, the smaller the measure of defects it took to achieve a given output" (Kotarbiński 1965, 121). The degree of productivity and savings depends on the ratio of the number of defects to how great the value of the output is. It follows that the minimal defects in comparison with their possible size do not prove any saving or cost-effective actions. The environmental practice often provides examples of ignorance or misunderstanding of these principles. As a result, actions are taken that have unintended consequences for humans, nature or entail negative economic consequences. An example of such a situation may be an investment consisting of the purchase and assembly of noise reduction equipment - assembly of acoustic silencers on "steam ejections" from the production process. If, in the course of the decision-making process, the price of such a device is the most important factor, rather than its effectiveness and durability, then in the future the company will have to face the consequences of this decision, which will be the exceeding of the legal limits for noise emissions into the environment and the associated financial penalties, as well as complaints from local residents who have to live in this environment (economic and social effect).

The general guidelines for efficient operation resemble the search for a measure between extreme cases. Specialisation and universality can be mentioned here. Specialisation improves action, for example in the case of continuous analyses and laboratory measurements as part of environmental impact monitoring. However, its repetitive nature may reduce the efficiency. Moreover, specialisation may be associated with a lack of general, universal knowledge, which makes it impossible to go beyond the routine and propose new solutions. Universalisation is associated with the possibility of taking decisions and actions in many areas. The complexity of environmental issues requires such a universal approach, although too far-reaching universalisation may lead to comprehensive dilettantism. According to Kotarbiński, the most beneficial in this case is to specialise in a specific narrow field, which becomes the starting point for incorporating further, new aspects related to the area of specialisation (Kotarbiński 1965, 213-218).

As any other action, environmental protection can be characterised by the most active behaviour of the agent. In praxeology, this is referred to as the activation of actions, in which all energy is used. The opposition here is a reduction in action. This limitation takes various forms: potentiation - replacing action with the disclosure of the possibility of action; automation - where possible, "machine-based" actions are introduced (e.g. procedures); instrumentalisation - the action includes machines and devices; pure surveillance - the position of the observer is assumed, intervention is minimized. Action is taken in emergencies requiring intervention. As Kieżun notes, "these forms generally result in a large increase in productivity and thus boost the organisation. With appropriate instrumentalisation, productivity increases, modern instrumentalisation reduces human activity yet makes the whole pro- 
cess extremely efficient; similarly, pure surveillance (e.g. in managerial work) often produces excellent results, increasing the productivity of subordinates, who are 'not disturbed' by the manager"(Kieżun 1997, 35).

The next guidelines concern the postponement, i.e. waiting for the right moment, and anticipation. In practical environmental protection measures, waiting too long to make a decision and then taking appropriate action may end up in an environmental disaster. In another context, a postponement is advisable due to the ability of many elements of the environment to self-regenerate and adapt. In some cases, too rapid action may also be ineffective. For instance, the exclusion of meadows from agricultural use, the purpose of which was to protect valuable areas of this type. It resulted in the disappearance of many species of fauna and flora in this area. Naturalists, having realised this situation, have taken action to encourage farmers to mow meadows, including financial incentives in the form of subsidies for such activities.

Another directive on efficient operation is particularly important in environmental practice. The idea is to maintain a certain level of resources and to make full use of resources. An example of this is the temperance that has been advocated in environmental protection measures, the avoidance of unjustified consumption, the taking into account of the limited and finiteness of resources on Earth, as well as the life cycle analysis carried out in manufacturing enterprises, etc.

The last pair of contradictory guidelines is the concentration of forces - securing all courses of action. The concentration of forces implies influencing a small number of elements, selecting a specific area of action and concentrating all attention and resources on that area. An example in the environmental field is the fight against greenhouse gas emissions or the management of significant environmental aspects. The second case refers to a situation where different courses of action are taken
(Kieżun 1997, 23-25). An example would be international meetings held as part of climate summits.

For these antinomies, in the context of efficient operation, it is necessary to assess which of the guidelines prevail in a particular situation. This is the basis for determining the course of action, placed between extremes. The decision is a regulator of options including a maximum scale of possibilities (Kieżun 1997, 25). The presented approach seems to reflect Aristotle's theory of the golden mean.

The review of the values and guidelines for efficient operation has made it possible to determine their suitability for environmental protection. It revealed their importance in the decision-making process, especially at the stage of checking and optimizing the analysed scheme of conduct. It can therefore be concluded that the decision-making process in the field of environmental protection will be inefficient or will be defective, resulting in a lack of positive effects in the social, natural and economic areas, if its praxeological conditions are not taken into account. This should be emphasised, as until now in environmental practice they have not always been given due importance. It would be interesting to incorporate at least basic praxeological guidelines directly into a formalised environmental management system. The forms of efficient operation could be applied at the design stage (planning, optimization) (Gasparski 1991, 69-78) and the stage of evaluation of the implemented action within the model referred to in the formalised environmental management system.

\section{Conclusions}

Examining the appropriate structure of the decision-making process, including its key stages, provides an opportunity to develop a specific scheme of conduct. Consideration of the context in which this process takes place and its conditions contribute to its effectiveness and efficiency. The conducted analyses made it possible to indicate the context, appropriate 
structure and praxeological conditions of the decision-making process in environmental protection. If the issue of optimization with as precise an approach to the decision-making process as possible is still relevant in this context, then it seems that we are close to indicating a complete decision-making pattern. However, a closer look at the decision at the stage of optimization (understood as the choice of a specific - most effective or efficient - action) will reveal that not only the area related to the praxeological guidelines of efficient operation is present at this stage, but also the issue of choice. Therefore, it is necessary to determine what this choice will refer to. While the optimization perspective, understood in accordance with the terms of our considerations, and also understood as the principle of rational resource management or cost-effective operation, constitutes a necessary condition for developing organisational effectiveness, it is insufficient (Gasparski 2013, 460-473; Gasparski 2004, 49-77). At the same time, "[...] there can be no optimization of economic processes without axiological, ethical and cultural reflection" (Krupa 2005, 344). According to Gasparski "A professional is one who follows the standards of a given profession [...]. These standards provide for themselves an axiological context of the 'triple E' - praxeological efficiency (effectiveness), cost-effectiveness and ethical values" (Gasparski 2004, 174-175). The decision-making process, founded on the axiological ground, may be incorrect due to the fact that its participants are not aware of this fact. Therefore, they ignore in the decision-making process issues related to certain (moral) standards of conduct with regard to the behaviour (actions) of persons and organisations related to environmental protection.

It should be stressed that the indicated characteristics of the components and the decision-making process preceding the environmental protection measures reveal its complexity. This results in problems that arise from the fact that the decision-making process is entangled in a variety of conditions. They will vary, depending on whether they concern an individual or a community. In this respect, it is also important what characteristics they will have, in other words, how the profile of the agent will be determined. Regardless, both an individual and a group of people will have a certain amount of knowledge, experience, convictions, beliefs, prejudices, various biological or cultural backgrounds, etc., which will influence the quality and course of the decision-making process. The decision-making process is praxeologically and axiologically determined, which also entails specific consequences and sometimes difficulties (e.g. related to the definition of a generally accepted catalogue of values). (e.g. related to the definition of a generally accepted catalogue of values). Legal, economic, social, environmental, political and other issues also have a significant impact on its course. Difficulties arise when it is necessary to decide which of these conditions should be taken into account and which should be omitted (Strzałecki 1991, 79-93). Disregarding some aspect may result in negative side effects, which the decision-maker was not able to predict at the design stage.

A critical point in the entire decision-making process is the design stage, in which optimization plays a key role, in relation to the proposed M. Mazur system. The main issue at this stage is the ability to anticipate the side-effects of each of the measures to ensure that the objective stated in the postulation is achieved. It is therefore important to develop adequate tools to reduce the likelihood of mistakes at this stage. In environmental management practice, risk analysis is successfully applied in this respect.

Regardless of the difficulties that arise during the process of discovering the characteristics and conditions of the environmental decision-making process, it seems that, apart from the internal and external conditions of the decision-maker themselves, it is possible to identify certain components of the environmental decision-making process which may not 
guarantee absolute perfection of the decision-making process, although they definitely increase the likelihood of achieving the postulated objectives. The structure and subsequent stages of the process can be pointed out here. It is also necessary to note the praxeological forms and general guidelines for efficient operation, which may be applied at the optimization stage and at the stage of checking the effectiveness of decisions taken. The context in which the process takes place may also contribute to this. It is proposed that at least economic, environmental and social issues should be included in the decision-making process. They entail the need to refer to certain values. This reference also derives from the pragmatics of reasonable management. Environmental protection measures aimed at enabling human beings to live, survive and develop also require a reference to values. It should be stressed that the difficulties encountered in the decision-making process must not be a reason to ignore the essential components of the process.

\section{Bibliography}

Act 2001 - Act of 27 April 2001 on Environmental Law (Dz.U. 2001 item 62, 627) (Dz.U. - Journal of Laws of the Republic of Poland).

Boć, Jan, Elżbieta Samborska-Boć, i Konrad Nowacki. 2008. Ochrona Środowiska. Wrocław: Wydawnictwo Kolonia Limited.

Borys, Tadeusz. 2013. „Rozwój”. W Biznes, etyka, odpowiedzialność. Podręcznik akademic$k i$, red. Wojciech Gasparski, 560. Warszawa: Wydawnictwo Naukowe PWN.

Dobrzański, Grzegorz. 2009. „Podstawowe pojęcia i problemy użytkowania i ochrony środowiska." W Ochrona środowiska przyrodniczego, red. Grzegorz Dobrzański, 19-48. Warszawa: Wydawnictwo Naukowe PWN.

Dołęga, Józef M. 1998. Człowiek w zagrożonym środowisku. $Z$ podstawowych zagadnień sozologii. Warszawa: Wydawnictwo ATK.

Dołęga, Józef M. 2002. „U podstaw kultury ekologicznej." W Podstawy kultury ekologicznej, red. Józef M. Dołęga, 7-8. Olecko: Wydawnictwo Wszechnicy Mazurskiej.

Gasparski, Wojciech. 1991. „Metodologia projektowania a metodologia ogólna i metodolo- gia nauk praktycznych." W Logika, praktyka, etyka: przestania filozofii Tadeusza Kotarbińskiego, red. Wojciech Gasparski, i Andrzej Strzałecki, 69-78. Warszawa: Wydawnictwo Towarzystwa Naukowego Prakseologii.

Gasparski, Wojciech. 2004. Wyktady z etyki biznesu. Nowa edycja. Warszawa: Wydawnictwo WSzPiZ im. Leona Koźmińskiego.

Gasparski, Wojciech. 2013. „Teorie oraz dylematy etyczne i prakseologiczne." W Biznes, etyka, odpowiedzialność, red. Wojciech Gasparski, 460-473. Warszawa: Wydawnictwo Naukowe PWN.

Hull, Zbigniew. 1990. „Świadomość kryzysu $i$ kryzys świadomości, czyli człowiek wobec przyrody." Biuletyn Naukowy ART 1(6): 93-99.

Hull, Zbigniew. 1998. „Istota i uwarunkowania obecnego kryzysu ekologicznego." W Humanistyka Przyrodoznawstwo Technika w obliczu kryzysu biosfery. Materiaty IV Olsztyńskiego Sympozjum Ekologicznego Olsztyn - Waplewo 10-12 września 1997, red. Jan Dębowski, 23-31. Olsztyn: Wyższa Szkoła Pedagogiczna.

Hull, Zbigniew. 2006. „Ekofilozofia i środowisko przyrodnicze." Diametros - Internetowy Serwis Filozoficzny 9: 105-115.

Kay, John. 2010. „Trudna sztuka decydowania.” Dziennik Gazeta Prawna 74(2705): 21-22.

Kempisty, Maria. 1973. „Otoczenie.” W Maty stownik cybernetyczny, red. Maria Kempisty, 291. Warszawa: Wydawnictwo Wiedza Powszechna.

Kieżun, Witold. 1997. Sprawne zarzadzanie organizacja. Zarys teorii i praktyki. Warszawa: Oficyna Wydawnicza SGH.

Kosewski, Marek. 2008. Wartości, godność $i$ władza. Warszawa: Wydawnictwo VIZJA Press \& IT.

Kotarbiński, Tadeusz. 1965. Traktat o dobrej robocie. Wrocław - Warszawa - Kraków: Wydawnictwo Naukowe PAN.

Krupa, Marian. 2006. „Dżungla’ teorii organizacji i zarządzania - poznanie zdeterminowane pytaniem o światopogląd?" Annales. Etyka w życiu gospodarczym 9: 339-349.

Lonc, Elżbieta, i Ewelina Kantowicz. 2005. Ekologia i ochrona środowiska. Podręcznik dla studentów. Wałbrzych: Wydawnictwo Państwowej Wyższej Szkoły Zawodowej im. Angelusa Silesiusa. 
Mazur, Mazur. 1976. Cybernetyka i charakter. Warszawa: Wydawnictwo PIW.

Michnowski, Lesław. 1999. Czy regres człowieczeństwa? Warszawa: Wydawnictwo Ludowe Towarzystwo Naukowo-Kulturalne.

Michnowski, Lesław. 2003. „O potrzebie budowy informacyjnych podstaw trwałego rozwoju (sustainable development) polskiej, europejskiej i światowej społeczności." W Filozoficzne $i$ spoteczne uwarunkowania zrównoważonego rozwoju, red. Artur Pawłowski, 107-119. Lublin: Wydawnictwo Naukowe PAN.

Piecuch, Czesława. 1983. „Człowiek w sytuacjach granicznych w ujęciu Karla Jaspersa.” Znak 9(346): 1392-1405.

Piontek, Franciszek. 2007. „Teoria rozwoju a personalistyczna koncepcja teorii ekonomicznej." W Zarzadzanie rozwojem. Aspekty spoteczne, ekonomiczne i ekologiczne, red. Barbara Piontek, i Franciszek Piontek, 55-62. Warszawa: Polskie Wydawnictwo Ekonomiczne.

Polski Komitet Normalizacyjny. 2005. PN-EN ISO 14001. Systemy Zarzadzania Środowiskowego - wymagania $i$ wytyczne stosowania. Warszawa: Wydział Wydawnictw Normalizacyjnych.

Poskrobko, Bazyli. 2007. Zarządzanie środowiskiem. Warszawa: Polskie Wydawnictwo Ekonomiczne.
Pszczołowski, Tadeusz. 1984. Organizacja od dotu $i$ od góry. Warszawa: Wydawnictwo Wiedza Powszechna.

Strzałecki, Andrzej. 1991. „Reguły i style rozwiązywania problemów praktycznych." W Logika, praktyka, etyka: przestania filozofii Tadeusza Kotarbińskiego, red. Wojciech Gasparski, i Andrzej Strzałecki, 79-93. Warszawa: Wydawnictwo Towarzystwa Naukowego Prakseologii.

Szaniawski, Klemens. 1994a. „Filozofia podejmowania decyzji." W O nauce, rozumowaniu $i$ wartościach. Pisma wybrane, red. Klemens Szaniawski, 431-444. Warszawa: Wydawnictwo Naukowe PWN.

Szaniawski, Klemens. 1994b. „Informacja a decyzja." W O nauce, rozumowaniu $i$ wartościach. Pisma wybrane, red. Klemens Szaniawski, 253-266. Warszawa: Wydawnictwo Naukowe PWN.

Szaniawski, Klemens. 1994c. „Prakseologia a teoria decyzji." W O nauce, rozumowaniu $i$ wartościach. Pisma wybrane, red. Klemens Szaniawski, 77-87. Warszawa: Wydawnictwo Naukowe PWN.

Zięba, Stanisław. 2013. Życie. Koncepcja emergentystyczna. Warszawa: Wydawnictwo Naukowe PWN.

Żylicz, Tomasz. 2004. Ekonomia środowiska $i$ zasobów naturalnych. Warszawa: Polskie Wydawnictwo Ekonomiczne. 